\title{
Wild radish (Raphanus sativus var. hortensis $f$. (4) raphanistroides) root extract protects neuronal cells by inhibiting microglial activation
}

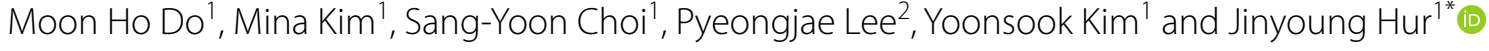

\begin{abstract}
External stimulus-induced activation of microglia plays an important role in the protection of neurons in the central nervous system; however, over-activation of microglia could cause neuronal damage, and it is implicated in the pathogenesis of neurodegenerative diseases. The aim of the present study was to investigate the effects of wild radish (Raphanus sativus var. hortensis f. raphanistroides) root extract (WRE) on microglial over-activation. Mouse microglia BV-2 cells and rat primary microglia were stimulated with lipopolysaccharide (LPS), treated with WRE, and analyzed for nitric oxide (NO) production, pro-inflammatory cytokine secretion, inducible NO synthase (iNOS) expression, and p38 kinase phosphorylation. Human neuroblastoma SH-SY5Y cells were treated with microglia-conditioned medium and analyzed for cell viability. Stimulation with LPS increased NO production and iNOS expression in BV-2 cells and primary microglia, but the treatment with WRE decreased both. Furthermore, WRE downregulated the mRNA expression and secretion of inflammatory cytokines interleukin-1 beta (IL-1 $\beta$ ) and tumor necrosis factor alpha (TNF-a), and inhibited the phosphorylation of p38 in LPS-activated microglia. Treatment with the conditioned medium of LPSinduced BV-2 cells decreased the viability of SH-SY5Y cells, but the damaging effect was significantly alleviated in cells treated with the conditioned medium of LPS plus WRE-cultured microglia. This indicated that the WRE treatment of microglia could protect neuronal cells from microglial activation-induced neurotoxicity. WRE may be a potential food product to attenuate neuroinflammation via the inhibition of microglial over-activation, which can slow down the neurodegenerative processes in the brain.
\end{abstract}

Keywords: Microglia, Raphanus sativus var. hortensis f. raphanistroides, Lipopolysaccharide, Inflammation, Nitric oxide, Neuroprotection

\section{Introduction}

Raphanus sativus (radish) and $R$. sativus var. hortensis $f$. raphanistroides Makino [Korean wild radish (WR)] are root vegetables belonging to the family Brassicaceae. These radish species mostly grow in coastal areas and are popular in Asia, where they have been traditionally used as a medicinal food to treat hepatotoxicity and indigestion $[1,2]$. Biologically active molecules in radish, such

\footnotetext{
*Correspondence: jyhur@kfri.re.kr

${ }^{1}$ Korea Food Research Institute, 245, Nongsaengmyeong-ro, Wanju-gun,

Jeollabukdo 55365, Republic of Korea

Full list of author information is available at the end of the article
}

as phenolic compounds, ferulic acid, glucosinolate, and sulforaphane, possess anti-oxidant, anti-inflammatory, and anti-cancer effects [3-8]. Among these components, ferulic acid has been reported to have antioxidant effects in Alzheimer's disease (AD) and other pathologic conditions [9]. Therefore, we speculated that ferulic acid could be one of the active component of WR.

Potential benefits of plant-derived antioxidants against various neurodegenerative disorders, including $A D$, have been emphasized; however, there is no information regarding the effects of radish on the central nervous system (CNS). Choi et al. [10] demonstrated that $R$. raphanistrum extracts can reduce lipid peroxidation and 
improve brain function in a mouse model of AD, suggesting that radish can protect against neurotoxic effects associated with oxidative stress. However, there are no reports on the effects of radish on microglia, the primary immune cells in the CNS.

Microglia function by scavenging damaged neurons and secreting neurotrophic factors to support neuronal survival and protect neurons from pathogens and other insults [11-15]. However, in the over-activated state, microglia promote neuronal cell death by releasing excessive amounts of pro-inflammatory factors such as nitric oxide (NO) and reactive oxygen species [16, 17], implicating microglial activation in the pathogenesis of progressive neurodegenerative brain diseases such as $\mathrm{AD}$, Parkinson's disease, and amyotrophic lateral sclerosis. Therefore, prevention of over-activation of microglia and inhibition of excessive inflammation may protect neurons from degeneration and maintain their survival.

Microglial cell line BV2 was originally immortalized from murine neonatal microglia by infection with a $v$-raf/ $v-m y c$ oncogene-carrying virus [18]. Because BV2 is easier to maintain than primary microglia, it is frequently used as an alternative to primary microglia [19]. However, immortalization may result in a different phenotype and disrupt normal physiological functioning of the primary microglia [20]. Therefore, we confirmed neurotoxic and neuroprotective activities using both BV2 and primary microglia derived from the forebrain of neonatal rats.

It has been demonstrated that various natural compounds suppress neuronal cell death by inhibiting microglial over-activation and neuroinflammation [21, 22], suggesting their potential application in the treatment of neurodegenerative diseases. Given the anti-inflammatory activity of radish, in this study, we investigated the ability of WR extract (WRE) to regulate the activation of microglia and reduce their neurotoxic activity. We also aimed to evaluate the potential of WRE in mitigating neurodegeneration. To the best of our knowledge, this is the first study to examine the neuroprotective effects of WRE in the context of microglial activation.

\section{Methods}

\section{Materials}

Lipopolysaccharide (LPS), 3-(4,5-dimethylthiazol2-yl)-2,5-diphenyltetrazolium bromide (MTT), $N^{5}$ [imino(methylamino)methyl]-L-ornithine citrate (L-NMMA, a NO synthase (NOS) inhibitor), and ferulic acid were purchased from Sigma-Aldrich (St. Louis, MO, USA). The primary antibodies against p38, phosphop38, and inducible NOS (iNOS) were obtained from Cell Signaling (Danvers, MA, USA) and $\beta$-actin antibody was purchased from Santa Cruz Biotechnology (Paso Robles, CA, USA).

\section{WR extraction}

Freshly dried roots of $R$. sativus var. hortensis f. raphanistroides Makino were supplied by Semyoung University (Chungcheongbuk-do, Korea) and authenticated by Professor Pyeongjae Lee in the Department of Natural Medicine Resources, Semyoung University. A sample of $R$. sativus, voucher specimen No. KFRI-MAT-0087, has been deposited at the Korea Food Research Institute. Crude extracts were prepared by sonicating the dried roots in $80 \%$ methanol and incubating for $24 \mathrm{~h}$. The extracts were filtered, evaporated, and powdered by freeze-drying.

\section{Ultra-performance liquid chromatography-tandem mass spectrometry (UPLC-MS/MS)}

To determine the amount of ferulic acid (4-hydroxy3-methoxycinnamic acid) in WR, the UPLC analysis was performed using an Acquity UPLC system (Waters, Miliford, MA, USA). MS/MS was performed by electrospray ionization (ESI) on a Waters Xevo TQ triplequadrupole mass spectrometer, and data were processed using MassLynx 4.1 (Waters) software. The auto-sampler was conditioned at $4{ }^{\circ} \mathrm{C}$ and the injection volume was 5 $\mu \mathrm{L}$. The mobile phase consisted of $10 \mathrm{mM}$ ammonium acetate and $0.2 \%$ formic acid in water (solvent $\mathrm{A}$ ) and $0.1 \%$ formic acid in acetonitrile (solvent $\mathrm{B}$ ). The flow rate was $0.35 \mathrm{~mL} / \mathrm{min}$, and gradient elution was conducted with the following protocol: $0-2 \mathrm{~min}, 90-90 \%$ solvent A; 2-3 min, $90-0 \%$ solvent A; $3-5 \mathrm{~min}, 0-0 \%$ solvent A; 5-5.5 min, 0-90\% solvent A. Chromatographic separation was achieved on an Acquity UPLC BEH C18 column $(2.1 \mathrm{~mm} \times 100 \mathrm{~mm}, 1.7 \mu \mathrm{m})$ at $40{ }^{\circ} \mathrm{C}$, and the total run time was $7 \mathrm{~min}$. The LC-MS/MS system was operated in the negative ESI mode, and scanning was performed in the multiple reaction monitoring (MRM) mode. The precursor to the product ion transition of ferulic acid was monitored at $m / z \quad 192.9 \rightarrow m / z$ 134.0. The capillary and cone voltages were $2.5 \mathrm{kV}$ and $20 \mathrm{~V}$, respectively, cone gas flow was $50 \mathrm{~L} / \mathrm{h}$, and collision energy was set at $15 \mathrm{~V}$. The source and desolvation gas temperatures were 150 and $400{ }^{\circ} \mathrm{C}$, respectively, and desolvation gas flow was 800 $\mathrm{L} / \mathrm{h}$.

\section{Cell culture}

BV-2 murine microglia and SH-SY5Y human neuroblastoma cells were obtained from American Type Culture Collection (Manassas, VA, USA). The cells were cultured in Dulbecco's modified Eagle's medium (DMEM) containing $10 \%$ fetal bovine serum and $1 \%$ 
penicillin-streptomycin. SH-SY5Y cells were differentiated using $10 \mu \mathrm{m}$ retinoic acid and 1\% FBS.

Primary microglial cells were obtained from the forebrain of newborn Sprague-Dawley rats in accordance with the guidelines of the Animal Care and Use Committee of the Korea Food Research Institute (KFRIM-14009). Rats on postnatal days 1-2 were rinsed with $70 \%$ ethanol and quickly euthanized by decapitation under the supervision of veterinary experts.

The rat primary microglial cultures were performed following the method of Antonellla et al. with modifications [23]. Briefly, the forebrain samples of neonatal rats were isolated and chopped. The tissues were then dissociated by mechanical disruption using a nylon mesh. The cells were seeded into T-75 flasks, and after 10-14 days of culture, primary microglia were isolated by mild trypsinization $(0.05 \%)$. Isolectin B4 staining was performed to determine the microglia culture purity, which was more than $95 \%$ (data not shown). Primary microglial cells were pre-treated in the presence or absence of WRE $(1,10$, and $50 \mu \mathrm{g} / \mathrm{mL})$ for $2 \mathrm{~h}$, and then exposed to LPS $(2 \mu \mathrm{g} / \mathrm{mL})$ for $24 \mathrm{~h}$ and analyzed for viability using the MTT assay.

\section{Conditioned medium culture}

The ability of WRE to inhibit the toxic effects of overactivated microglia on neurons was investigated using microglia-conditioned medium (CM). To obtain CM, BV2 microglia were treated with LPS $(2 \mu \mathrm{g} / \mathrm{mL})$ or LPS plus WRE $(50 \mu \mathrm{g} / \mathrm{mL}, 2-\mathrm{h}$ pretreatment $)$ for $24 \mathrm{~h}$, and the supernatant was collected and centrifuged. SH-SY5Y cells were seeded at a density of $1 \times 10^{6}$ cells $/ \mathrm{mL}$, cultured for $24 \mathrm{~h}$, treated with conditioned medium for $24 \mathrm{~h}$, and performed the MTT assay to determine cell viability.

\section{NO assay}

BV2 cells were seeded in 96-well plates, pre-treated or not with WRE for $2 \mathrm{~h}$, and treated with LPS for $24 \mathrm{~h}$; then, the concentration of nitrite (a product of $\mathrm{NO}$ oxidation) in the medium was analyzed. For this, the cell supernatant $(50 \mu \mathrm{L})$ was mixed with an equal volume of Griess reagent ( $1 \%$ sulfanilamide and $0.1 \% N$-1-napthylethylenediamine dihydrochloride in $5 \%$ phosphoric acid), and the concentration of $\mathrm{NO}$ was measured after $10 \mathrm{~min}$ at $540 \mathrm{~nm}$ using a microplate reader (Molecular Devices, Sunnyvale, CA, USA); sodium nitrite was used as the standard to calculate nitrite concentration.

\section{Western blotting}

To determine p38 and phospo-p38 expression, the cells were pretreated without or with WRE for $2 \mathrm{~h}$ and then with LPS for $1 \mathrm{~h}$. For iNOS expression, the cells were pre-treated without or with WRE for $2 \mathrm{~h}$ followed by LPS treatment for $24 \mathrm{~h}$. Proteins were extracted using lysis buffer containing $50 \mathrm{mM}$ Tris- $\mathrm{HCl}(\mathrm{pH} 8.0), 150 \mathrm{mM}$ $\mathrm{NaCl}, 0.02 \%$ sodium azide, $0.1 \%$ SDS, $1 \%$ Nonidet P- 40 , $0.5 \%$ sodium deoxycholate, $1 \mathrm{mM}$ phenylmethylsulfonyl fluoride. Protein concentration was determined using the Bio-Rad Protein Assay Kit (Bio-Rad, Hercules, CA, USA). The proteins were loaded in $10 \%$ for p38 and phosph-p38 and $8 \%$ gels for iNOS, subjected to SDS-polyacrylamide gel electrophoresis, and transferred onto a nitrocellulose membrane. The membrane was blocked with $5 \%$ skim milk for $1 \mathrm{~h}$ and was incubated overnight at $4{ }^{\circ} \mathrm{C}$ with primary antibodies against iNOS, p38, phospho-p38, and $\beta$-actin. The membrane was then washed and incubated with horseradish peroxidase-conjugated secondary antibodies, and the protein bands were observed using the ECL reagent (Thermo Fisher Scientific, Chicago, IL, USA).

\section{Enzyme-linked immunosorbent assay (ELISA)}

The cells were seeded in 24-well plates, pre-treated or not with WRE for $2 \mathrm{~h}$, and then treated with LPS for $24 \mathrm{~h}$. The levels of pro-inflammatory cytokines interleukin 1 beta (IL-1 $\beta$ ) and tumor necrosis factor alpha (TNF- $\alpha$ ) in the supernatants of cells were measured using ELISA kits (Invitrogen, Carlsbad, CA, USA), according to the manufacturer's protocol.

\section{Real-time PCR (RT-PCR)}

The cells were seeded in six-well plates, pre-treated without or with WRE for $2 \mathrm{~h}$, and then with LPS for $24 \mathrm{~h}$. The total RNA was extracted using NucleoSpin ${ }^{\circledR}$ RNA (Macherey-Nagel, Duren, Germany), and the RNA concentration was measured using NanoDrop One/One ${ }^{\mathrm{c}}$ (Thermo Fisher Scientific). Complementary DNA was synthesized using the iScript ${ }^{\mathrm{TM}}$ cDNA Synthesis Kit (Bio-Rad) and used as a template in the RT-PCR performed with SYBR Green (Bio-Rad) on a CFX96 ${ }^{\mathrm{TM}}$ Real-Time PCR Detection System (Bio-Rad). Primer sequences used were as follows: 5 '-CATCTTCTCAAAATTCGAGTGACAA- $3^{\prime}$ (forward) and $5^{\prime}$-ACTTGGGCAGATTGACCTCAG-3' (reverse) for TNF- $\alpha$; 5'-GCAACTGTTCCTGAACTC $-3^{\prime}$ (forward) and 5'-CTCGGAGCCTGTAGTGCA-3' (reverse) for $I L-1 \beta$; and $5^{\prime}$-ATCCTGAAAGACCTCTAT GC-3' (forward) and 5'-AACGCAGCTCAGTAACAG $\mathrm{TC}-3^{\prime}$ (reverse) for $\beta$-actin. Relative mRNA expression was determined using the comparative delta $\mathrm{Ct}\left(2^{-\Delta \Delta \mathrm{Ct}}\right)$ method after normalization to the $\beta$-actin $\mathrm{Ct}$ values.

\section{Statistical analysis}

The data are presented as mean \pm standard deviation. Student's $t$-test and one-way analysis of variance were performed to compare two independent and multiple independent datasets (post hoc Tukey's test) with normal distribution. 


\section{Results}

Identification and quantification of ferulic acid in WRE by UPLC-MS/MS

We measured ferulic acid concentration in WRE by UPLC-MS/MS based on the peak area and calibration curve (Fig. 1). The concentration of ferulic acid was $216.37 \pm 6.85 \mu \mathrm{g} / \mathrm{g}$ WRE.

\section{Inhibitory effect of WRE on over-activated microglia}

WRE $(1-50 \mu \mathrm{g} / \mathrm{mL})$ reduced NO production by activated microglia in a concentration-dependent manner: 1,10 , and $50 \mu \mathrm{g} / \mathrm{mL}$ WRE reduced the NO level from $23.0 \mu \mathrm{M}$ to $18.2,15.2$, and $9.8 \mu \mathrm{M}$, respectively, in BV-2 cells (Fig. 2a), and from $32 \mu \mathrm{M}$ to 29.3, 21.0, and $14.3 \mu \mathrm{M}$, respectively, in rat primary microglia (Fig. 2b). It should be noted that WRE alone did not promote NO release (Fig. 2c) and did not affect cell viability (Fig. 2d-f), indicating that the decrease in NO production was due to specific effects of WRE on LPS-activated microglia and not its cytotoxicity.

\section{Effects of WRE on the secretion of pro-inflammatory cytokines}

In BV-2 cells, LPS caused a ninefold increase in the TNF- $\alpha$ level, but treatment with $50 \mu \mathrm{g} / \mathrm{mL}$ WRE decreased it by $70 \%$ compared with the levels in cells

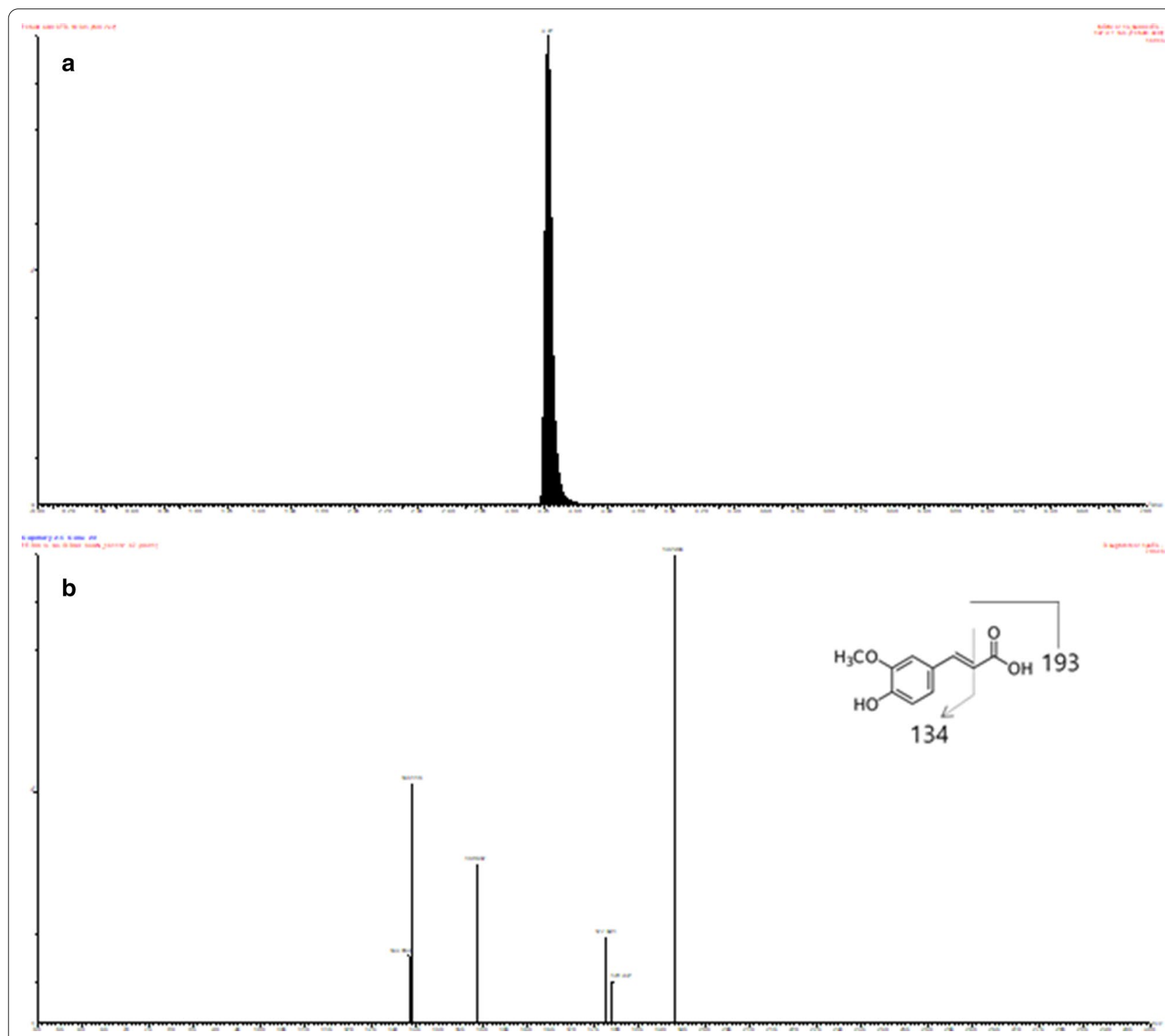

Fig. 1 Analysis of ferulic acid content in wild radish extract (WRE). Representative ultra-performance liquid chromatography-tandem mass spectrometry (UPLC-MS/MS) chromatograms (a) and full-scan product ion spectra of $(\mathrm{M}+\mathrm{H})+$ ions and fragmentation $(\mathbf{b})$ of ferulic acid are shown 


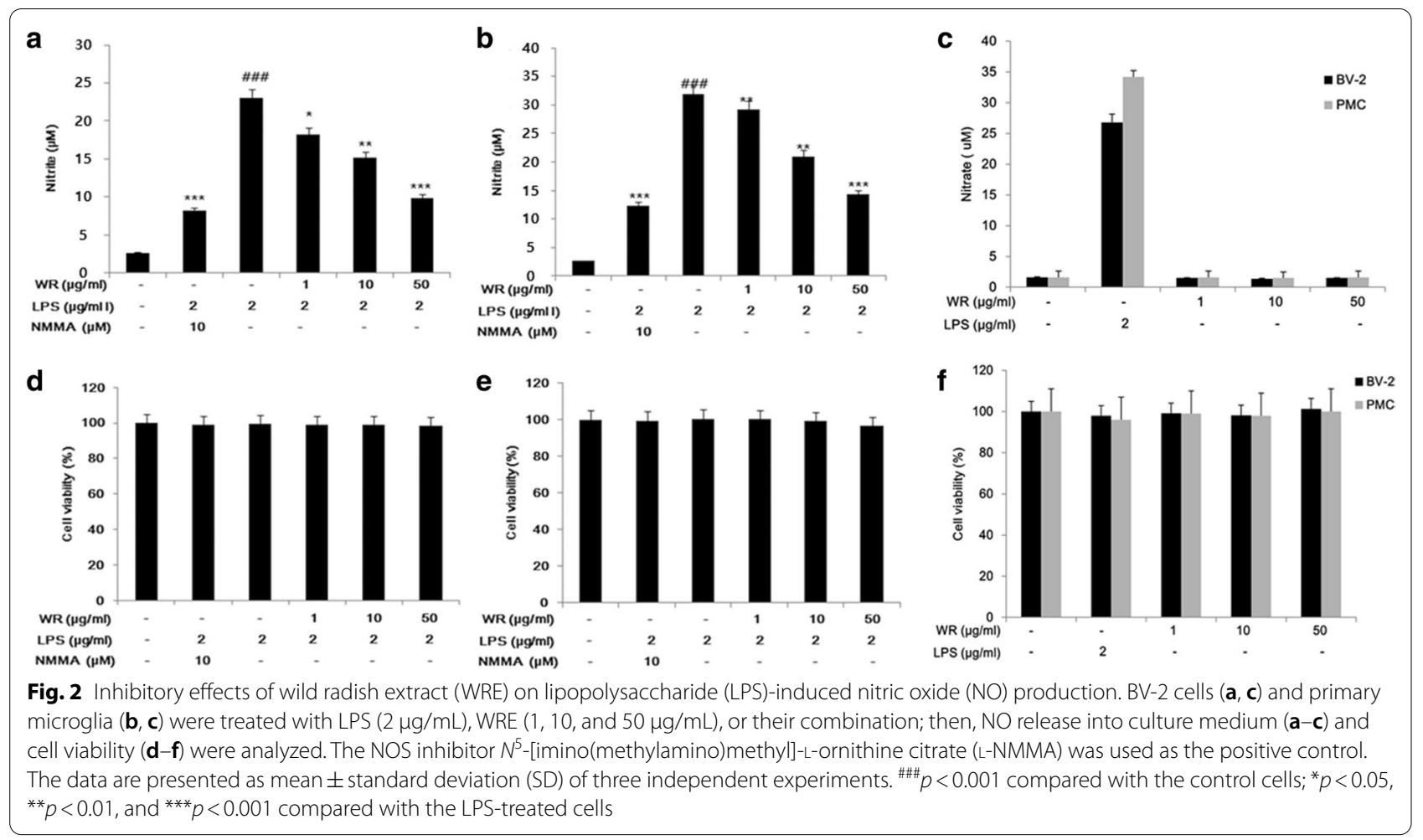

cultured with LPS alone; however, 1 and $10 \mu \mathrm{g} / \mathrm{mL}$ WRE had no effect (Fig. 3a). The IL-1 $\beta$ level was increased by fourfold by LPS treatment; however, WRE at 10 and
$50 \mu \mathrm{g} / \mathrm{mL}$ decreased it by $30 \%$ and $60 \%$, respectively (Fig. 3b). Consistent with these results, LPS caused a four and twofold increase in the TNF- $\alpha$ and $I L-1 \beta$ mRNA

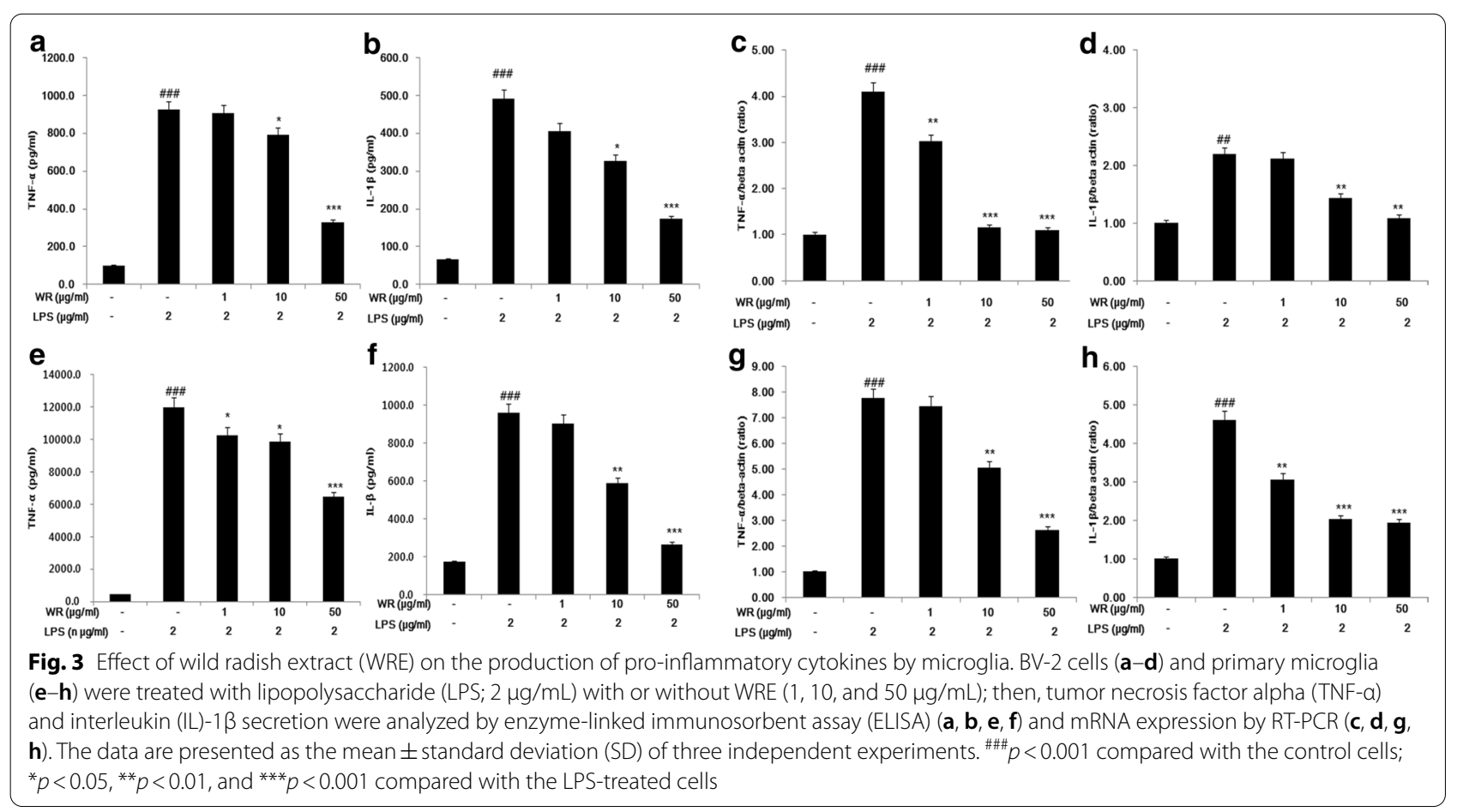


levels, respectively, whereas WRE, in a dose-dependent manner, significantly attenuated these effects. The cells treated with $50 \mu \mathrm{g} / \mathrm{mL}$ WRE presented mRNA levels similar to those in the (LPS-untreated) control group (Fig. 3c, d).

Similar results were obtained in primary microglial cells; LPS considerably induced TNF- $\alpha$ and IL- $1 \beta$ secretion (28 and 5 times, respectively), whereas WRE reduced it in a dose-dependent manner (Fig. 3e, f). The TNF- $\alpha$ level in the medium was reduced to $50 \%$ by $50 \mu \mathrm{g} / \mathrm{mL}$ WRE and the IL- $1 \beta$ level was reduced to $50 \%$ and $80 \%$ by 10 and $50 \mu \mathrm{g} / \mathrm{mL}$ WRE, respectively, compared with their levels in the LPS group. The same trend was observed for the mRNA expression of TNF- $\alpha$ and $I L-1 \beta$, which were considerably upregulated by LPS but downregulated (to $70 \%$ and $60 \%$, respectively) by $50 \mu \mathrm{g} / \mathrm{mL}$ WRE (Fig. $3 \mathrm{~g}$, h). These results indicate that WRE could inhibit the expression of pro-inflammatory cytokines in over-activated microglia.

\section{Inhibitory effects of WRE on iNOS expression}

WRE, in a dose-dependent manner, decreased the expression of iNOS in LPS-stimulated BV-2 cells, although the effect was significant only at $50 \mu \mathrm{g} / \mathrm{mL}$ (Fig. 4a). WRE also tended to downregulate iNOS expression in primary microglia treated with LPS; however, the decrease was not significant (Fig. 4b).

\section{Regulatory effects of WRE on p38 phosphorylation}

The western blotting analysis showed that there was a 13-fold increase in p38 phosphorylation in LPS-treated BV-2 cells, but the increase was significantly attenuated in the WRE + LPS group (Fig. 4c). A similar trend was observed in primary microglia, where LPS-induced p38 phosphorylation was reduced by WRE (Fig. 4d).

\section{Reduced neurotoxicity of WRE-treated microglia}

The treatment with the control CM supplemented with LPS did not affect the viability of SH-SY5Y cells; however, this was reduced by the CM of LPS-treated BV-2 cells to $58 \%$, whereas the CM of WRE + LPS cells attenuated this negative effect by $86 \%$ (Fig. 4e). These findings indicate that the inhibition of microglial pro-inflammatory activity by WRE could increase the survival of neuronal cells.

\section{Discussion}

Several studies have examined the protective effect of natural extracts and food products against neurodegenerative diseases such as $\mathrm{AD}$ [24-27], but the underlying physiological mechanisms are unclear. One of the mechanisms could be the activation of microglia, which are cells responsible for the immune response in the CNS. The immune system of the brain is clearly not absolute, and the CNS is sensitive to inflammatory events both inside and outside the brain. The effects of microglial activation on neurons can range from beneficial to detrimental. When over-activated, microglia release inflammatory factors and neurotoxins, including cytokines, NO, and reactive oxygen species, which trigger sustained inflammatory reactions leading to neuronal apoptosis [28, 29]. Another mechanism is increased oxidative stress in the brain, which induces protein, lipid, DNA, and RNA oxidation, thereby triggering neuronal damage [30]. Microglial activation and oxidative stress are considered to play a critical role in the pathogenesis of neurodegenerative disorders. Furthermore, the suppression of microgliamediated inflammation and oxidative stress has been shown to prevent neuronal damage [31-33], and this could be a potential strategy to treat neurodegeneration.

Korean wild radish has been reported to have anti-cancer effects, but its neuroprotective effects have not been reported [8]. Choi et al. reported the neuroprotective effects of radish by its antioxidant activity [9]; however, the study did not include Korean wild radish. Moreover, the antioxidant mechanism appeared only in neuron-like cells, and not in cell-to-cell interactions in the CNS. Therefore, we examined the effects of wild radish in terms of cell-to-cell interaction. Wild radish contains various phenolic compounds, and it is known to contain ferulic acid, which is known to be effective in improving neurodegenerative diseases [34, 35]. Therefore, we surmised that if Korean wild radish had neuroprotective effects, it would be due to ferulic acid, and its content was measured (Fig. 1).

BV2 is frequently used as an alternative to primary microglia [18], but this cell line may present results different from those of primary microglia because of different phenotypes and disruption of normal physiological functions [19]. Therefore, in this study, we evaluated the inhibitory activity of WR against LPSinduced microglial activation in both BV2 cells and primary microglial cells. In the present study, the WR extract inhibited LPS-induced NO production and iNOS expression in BV-2 and primary cultured microglia cells (Figs. 2 and 4). These similar results in BV2 and primary microglial cells provided evidence that WR has potential as a neuroprotective agent. Furthermore, the WR extract not only inhibited the synthesis of proinflammatory cytokines such as IL- $1 \beta$ and TNF- $\alpha$, but also reduced the gene expression of these cytokines (Fig. 3). Furthermore, WRE suppressed the phosphorylation of MAPK p38, implicated in the regulation of inflammatory responses to various stress stimuli such as osmotic shock, LPS, and UV [36-38]. It has been demonstrated that activated microglia induce inflammation via the phosphorylation-dependent activation 
a
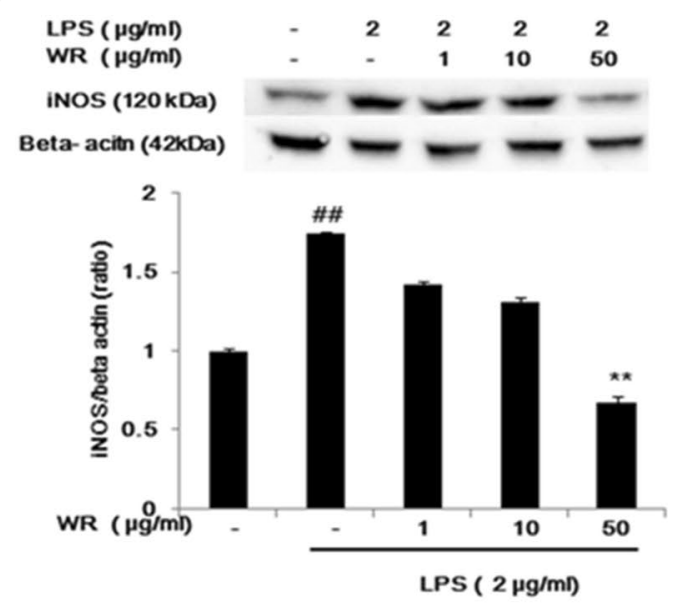

C
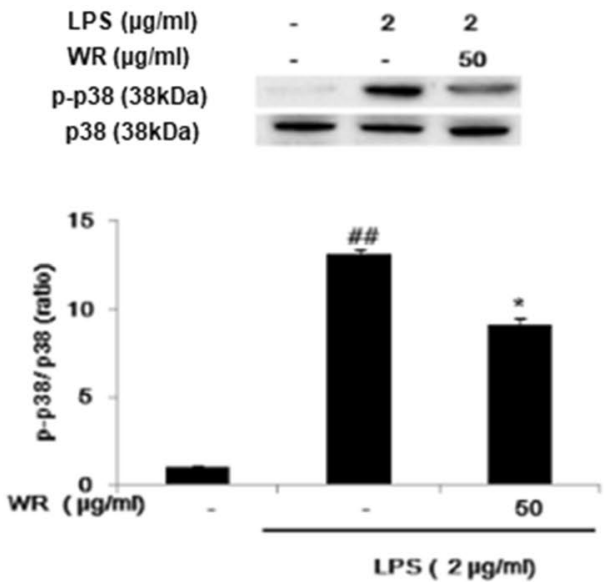

e

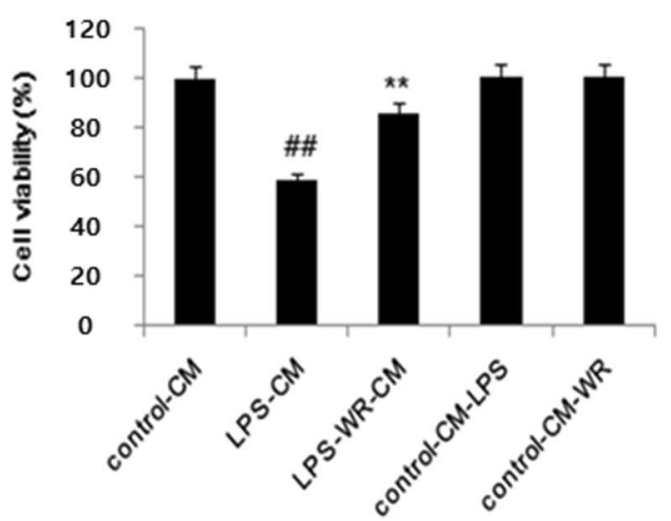

b
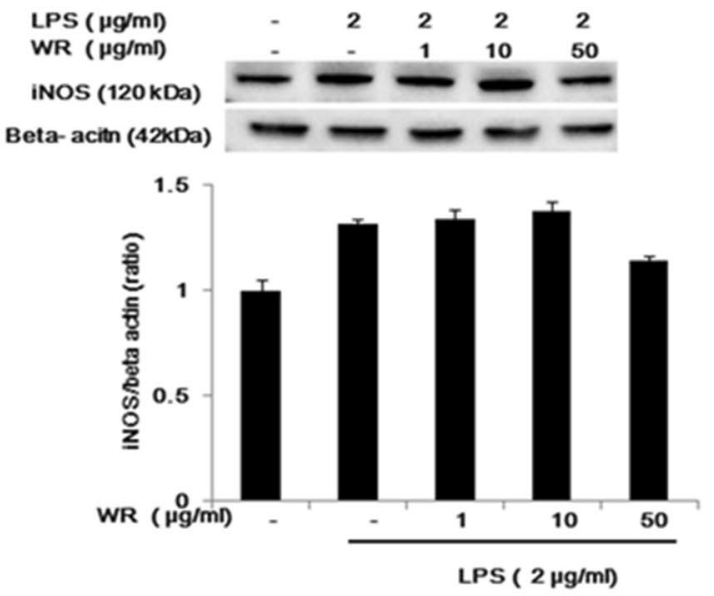

d
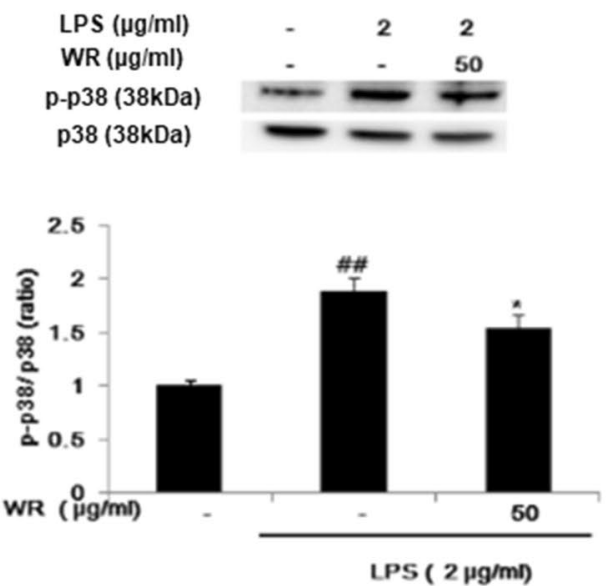

Fig. 4 Effects of wild radish extract (WRE) on inducible nitric oxide synthase (iNOS) expression, p38 phosphorylation, and neuronal cell survival. $\mathbf{a}-\mathbf{d}$ BV2 cells $(\mathbf{a}, \mathbf{c})$ and primary microglia (b, d) were treated with lipopolysaccharide (LPS) with or without WRE; then, iNOS expression and p38 phosphorylation were analyzed by western blotting. The bar graphs present the quantitative results normalized to $\beta$-actin expression; \#\# $p<0.01$ compared with the control and ${ }^{*} p<0.05$ and ${ }^{*} p<0.01$ compared with the LPS-treated cells. e SH-SY5Y neuroblastoma cells were cultured for $24 \mathrm{~h}$ with conditioned medium (CM) collected from BV-2 cells treated or not treated with LPS ( $2 \mu \mathrm{g} / \mathrm{mL})$ or LPS plus WRE $(50 \mu \mathrm{g} / \mathrm{mL})$; then, cell viability was analyzed using the MTT assay. Control-CM, CM from untreated microglia; Control-CM + LPS and Control-CM + WRE, CM from untreated microglia supplemented with LPS and WRE, respectively; LPS-CM and LPS-WRE-CM, CM from LPS-treated and LPS plus WRE-treated microglia, respectively. The data are presented as mean \pm standard deviation (SD) of three independent experiments; ${ }^{\#} p<0.01$ compared with Control-CM and ${ }^{* *} p<0.01$ compared with LPS-CM 
of p38, resulting in the enhanced expression of iNOS and secretion of pro-inflammatory cytokines [39].

Moreover, p38 is a well-known critical regulator of IL-1 $\beta$ and TNF $\alpha$ overproduction in microglia [40]. Thus, it can be speculated that WRE inhibited microglial over-activation by reducing p38 phosphorylation, which can downregulate the release of inflammatory mediators. However, it is possible that protein kinases other than $\mathrm{p} 38$ are involved in mediating the WRE effect on LPS-activated microglia.

The neuroprotective effect has been evaluated by treating SH-SY5Y cells with a conditioned medium of BV2 cells [41]. It is known that SH-SY5Y cells generally did not show cell death by LPS, but LPS-treated BV2 conditioned medium is known to reduce the viability of SH-SY5Y cells [42]. It might be that a neurotoxic substances produced and secreted by BV2 cells due to LPS treatment caused cytotoxicity to SH-SY5Y cells. As shown in Fig. 4, when SH-SY5Y cells were treated with conditioned media of cells treated with LPS alone or LPS + WR extract, neurotoxicity of the LPS + WR group was reduced compared with that of the LPS alone group. This can be attributed to the neuroprotective effect of biomolecules mediated by cell-to-cell interaction.

In the present study, WRE downregulated the production of NO and pro-inflammatory cytokines by LPS-activated microglia, and this attenuated the neurotoxicity of microglial CM on neuronal cells. These results suggest that WRE, via the inhibition of microglial over-activation, can protect neurons from the destruction by microglia-secreted pro-inflammatory and neurotoxic factors and act as an effective supplement for the prevention or treatment of neurodegeneration. However, further studies are needed to elucidate the protective mechanisms of WR on the other microglial activation pathway and cellto-cell interaction pathways.

\section{Abbreviations \\ WR: Wild radish; WRE:WR extract; AD: Alzheimer's disease; CNS: Central nerv- ous system; MTT: 3-(4,5-Dimethylthiazol-2-yl)-2,5-diphenyltetrazolium bro- mide; NO: Nitric oxide; iNOS: Inducible NO synthase; IL-1 13: Interleukin 1 beta; TNF-a: Tumor necrosis factor alpha; LPS: Lipopolysaccharide; CM: Conditioned medium.}

\section{Acknowledgments}

This work was supported by the Main Research Program (E0210300 and E0134104) of the Korea Food Research Institute (KFRI), funded by the Ministry of Science.

\section{Authors' contributions}

All authors read and approved the final manuscript.

Funding

Not applicable.
Availability of data and materials

All data generated or analyzed during this study are included in this published article [and its additional information files].

\section{Declarations}

\section{Competing interests}

The authors declare that they have no competing interests.

\section{Author details}

${ }^{1}$ Korea Food Research Institute, 245, Nongsaengmyeong-ro, Wanju-gun, Jeollabukdo 55365, Republic of Korea. ${ }^{2}$ Department of Natural Medicine Resources, Semyung University, Jecheon city, Republic of Korea.

Received: 8 December 2020 Accepted: 3 March 2021

Published online: 13 March 2021

\section{References}

1. Gutierrez RM, Perez RL (2004) Raphanus sativus (Radish): Their chemistry and biology. Sci World J 4:811-817

2. Hanlon PR, Webber DM, Barnes DM (2007) Aqueous extract from Spanish black radish (Raphanus sativus L. var. niger) induces detoxification enzymes in the HepG2 human hepatoma cell line. J Agric Food Chem 55:6439-6446

3. Beevi SS, Narasu ML, Gowda BB (2010) Polyphnolic profile, antioxidant and radical scavenging activity of leaves and stem of Raphanus sativus $\mathrm{L}$. Plant Foods Hum Nutr 65:8-17

4. Lugasi A, Blazovics A, Hagymasi K, Kocsis I, Kery A (2005) Antioxidant effect of squeezed juice from black radish (Raphanus sativus L. var niger) in alimentary hyperlipidaemia in rats. Phytother Res 19:587-591

5. Sun BY, Kan SH, Zhang YZ, Deng SH, Wu J, Yuan H (2010) Certain antioxidant enzymes and lipid peroxidation of radish (Raphanus sativus L.) as early warning biomarkers of soil copper exposure. J Hazard Mater 183:833-838

6. Yamanoshita O, Ichihara S, Hama H, Ichihara G, Chiba M, Kamijima M (2007) Chemopreventive effect of selenium-enriched Japanese radish sprout against breast cancer induced by 7,12-dimethylbenz[a]anthracene in rats. Tohoku J Exp Med 212:191-198

7. Kim SJ, Kim BS, Kyung TW, Lee SC, Rho CW, Choi KR (2006) Suppressive effects of young radish cultivated with sulfur on growth and metastasis of B16-F10 melanoma cells. Arch Pharm Res 29:235-240

8. Choi SJ, Choi ARC, Cho EH, Kim SY, Lee GS, Lee SS (2009) The glucosinolate and sulforaphane contents of Land Race Radish and Wild Race Radish extracts and their inhibitory effects on cancer cell lines. J East Asian Soc Diet Life 19:558-563

9. Antonellla S, Daniela G, Di Carlo M (2015) Ferulic acid: A hope for Alzheiemer's disease therapy from plants. Nutrients 7:5764-5782

10. Choi SJ, Park CK, Shin DH (2020) Protective effects of radish extract against neurotoxicity in mice and PC12 cells. J Med Food 23:1-12

11. Hanisch UK, Kettenmann H (2007) Microglia: Active sensor and versatile effector cells in the normal and pathologic brain. Nat Neurosci 10:1387-1394

12. Aloisi $F(2001)$ Immune function of microglia. Glia 36:165-179

13. Jung WK, Ahn YW, Lee SH, Choi YH, Kim SK, Yea SS (2009) Ecklonia cava ethanolic extracts inhibit lipopolysaccharide-induced cyclooxygenase-2 and inducible nitric oxide synthase expression in BV2 microglia via the MAP kinase and NF-kappaB pathways. Food Chem Toxicol 47:410-417

14. Choi Y, Lee MK, Lim SY, Sung SH, Kim YC (2009) Inhibition of inducible NO synthase, cyclooxygenase-2 and interleukin-1 beta by torilin is mediated by mitogen-activated protein kinases in microglial BV2 cells. Br J Pharmacol 156:933-940

15. Cohen-Lahav M, Douvdevani A, Chaimovitz C, Shany S (2007) The antiinflammatory activity of 1,25-dihydroxyvitamin D3 in macrophages. J Steroid Biochem Mol Biol 103:558-562

16. Long-Smith CM, Sullivan AM, Nolan YM (2009) The influence of microglia on the pathogenesis of Parkinson's disease. Prog Neurobiol 89:277-287

17. McGeer PL, Itagaki S, Tago H, McGeer EG (1987) Reactive microglia in patients with senile dementia of the Alzheimer type are positive for the histocompatibility glycoprotein HLA-DR. Neurosci Lett 79:195-200 
18. Blasi E, Barluzzi R, Bocchini V, Mazzolla R, Bistoni F (1990) Immortalization of murine microglial cells by a v-raf/v-myc carrying retrovirus. J Neuroimmunol 27:229-237

19. Das A, Kim SH, Arifuzzaman S, Yoon T, Chai JC, Lee YS, Park KS, Jung KH, Chai YG (2016) Transcriptome sequencing reveals that LPS-triggered transcriptional responses in established microglia BV2 cell lines are poorly representative of primary microglia. J Neuroinflamm 13:182-199

20. Agalave NM, Lane BT, Mody PH, Szabo-Pardi TA, Burton MD (2020) Isolation, culture, and downstream characterization of primary microglia and astrocytes from adult rodent brain and spinal cord. J Neurosci Methods 340:108742

21. Lee P, Hur J, Lee J, Kim J, Jeong J, Kang I (2006) 15,16-dihydrotanshinone I suppresses the activation of BV-2 cell, a murine microglia cell line, by lipopolysaccharide. Neurochem Int 48:60-66

22. Suk K, Ock J (2012) Chemical genetics of neuroinflammation: natural and synthetic compounds as microglial inhibitors. Inflammopharmacology 20:151-158

23. Saura J, Tusell JM, Serratosa J (2003) High-yield isolation of murine microglia by mild trypsinization. Glia 44:183-189

24. The Medical Letter, Inc (2009) A medical food for Alzheimer's disease. Med Lett Drugs Ther 51:49-50

25. Axona (Accera, Inc) (2010) A new medical food therapy for persons with Alzheimer's disease. Issues Ment Health Nurs 31:435-436

26. Kamphuis PJ, Verhey FR, Olde Rikkert MG, Twisk JW, Swinkels SH, Scheltens P (2011) Efficacy of a medical food on cognition in Alzheimer's disease: results from secondary analyses of a randomized, controlled trial. J Nutr Health Aging 15:720-724

27. Mielke MM, Leoutsakos JM, Corcoran CD, Green RC, Norton MC, WelshBohmer KA (2012) Effects of Food and Drug Administration-approved medications for Alzheimer's disease on clinical progression. Alzheimer's Dement 8:180-187

28. Venneti S, Wiley CA, Kofler J (2009) Imaging microglial activation during neuroinflammation and Alzheimer's disease. J Neuroimmune Pharmacol 4:227-243

29. Polazzi E, Monti B (2010) Microglia and neuroprotection: From in vitro studies to therapeutic applications. Prog Neurobiol 92:293-315

30. Cheignon C, Tomas M, Bonnefont-Rousselot D, Faller P, Hureau C, Collin $F$ (2018) Oxidative stress and the amyloid beta peptide in Alzheimer's disease. Redox Boil 14:450-464

31. McNaull BB, Todd S, McGuinness B, Passmore AP (2010) Inflammation and anti-inflammatory strategies for Alzheimer's disease-a mini-review. Gerontology 56:3-14

32. Halliday G, Robinson SR, Shepherd C, Kril J (2000) Alzheimer's disease and inflammation: a review of cellular and therapeutic mechanisms. Clin Exp Pharmacol Physiol 27:1-8
33. Marrazzo P, Angeloni C, Hrelia S (2019) Combined treatment with three natural antioxidants enhances neuroprotection in a SH-SY5Y 3D culture model. Antioxidants 8:420

34. Iyda JH, Fernandes Â, Ferreira FD, Alves MJ, Pires TC, Barros L (2019) Chemical composition and bioactive properties of the wild edible plant Raphanus raphanistrum L. Food Res Int 121:714-722

35. Rehman SU, Ali T, Alam SI, Ullah R, Zeb A, Lee K (2019) Ferulic acid rescues LPS-induced neurotoxicity via modulation of the TLR4 receptor in the mouse hippocampus. Mol Neurobiol 56:2774-2790

36. Raingeaud J, Gupta S, Rogers JS, Dickens M, Han J, Ulevitch RJ (1995) Proinflammatory cytokines and environmental stress cause p38 mitogenactivated protein kinase activation by dual phosphorylation on tyrosine and threonine. J Biol Chem 270:7420-7426

37. Adams JL, Badger AM, Kumar S, Lee JC (2001) p38 MAP kinase: Molecular target for the inhibition of pro-inflammatory cytokines. Prog Med Chem $38: 1-60$

38. Chaparro-Huerta V, Flores-Soto ME, Gudino-Cabrera G, Rivera-Cervantes MC, Bitzer-Quintero OK, Beas-Zarate C (2008) Role of p38 MAPK and proinflammatory cytokines expression in glutamate-induced neuronal death of neonatal rats. Int J Dev Neurosci 26:487-495

39. Yoo MS, Shin JS, Choi HE, Cho YW, Bang MH, Baek NI (2012) Fucosterol isolated from Undaria pinnatifida inhibits lipopolysaccharide-induced production of nitric oxide and pro-inflammatory cytokines via the inactivation of nuclear factor-kappaB and p38 mitogen-activated protein kinase in RAW264.7 macrophages. Food Chem 135:967-975

40. Bachstetter AD, Xing B, de Almeida L, Dimayuga ER, Watterson DM, Van Eldik LJ (2011) Microglial p38a MAPK is a key regulator of proinflammatory cytokine up-regulation induced by toll-like receptor (TLR) ligands or beta-amyloid (Aß). J Neuroinflamm 8:1-12

41. Yeo ETY, Wong KWL, See ML, Wong KY, Gan SY, Chan EWL (2018) Piper sarmentosum Roxb. confers neuroprotection on beta-amyloid (A $\beta$ )-induced microglia-mediated neuroinflammation and attenuates tau hyperphosphorylation in SH-SY5Y cells. J Ethnopharmacol 217:187-194

42. Liu Y, Fu Y, Zhang Y, Liu F, Rose GM, He X (2020) Butein attenuates the cytotoxic effects of LPS-stimulated microglia on the SH-SY5Y neuronal cell line. Eur J Pharmacol 868:172858

\section{Publisher's Note}

Springer Nature remains neutral with regard to jurisdictional claims in published maps and institutional affiliations.

\section{Submit your manuscript to a SpringerOpen ${ }^{\circ}$ journal and benefit from:}

- Convenient online submission

- Rigorous peer review

- Open access: articles freely available online

- High visibility within the field

Retaining the copyright to your article

Submit your next manuscript at $\boldsymbol{\nabla}$ springeropen.com 